\title{
PENSAMENTO E MOVIMENTO NO ESTUDO DA CORPOREIDADE
}

\author{
Maria Ignez de Souza Calfa ${ }^{\mathrm{i}}$ \\ Ruth Silva Torralba Ribeiro ${ }^{\text {ii }}$
}

\begin{abstract}
Resumo: Esse artigo tem como objetivo a compreensão da sala de aula como um espaço afetivo que aqui denominamos de "sala de visitas". Deste modo, se propõe a tecer no campo da dança, através de uma perspectiva aberta às diferenças, a valorização do estudo da corporeidade, apostando na ética e na poética no processo de ensino-aprendizagem. A partir de uma experiência com estudantes de um curso de bacharelado em dança, trazemos à cena uma experiência de educação que se interessa pela corporeidade, em que a arte de educar evidencia na dimensão sensível sua potência política. Entendemos que é preciso encontrar na ação "disciplinar" outros modos de produção de conhecimento, criando redes e tecendo conexões entre saberes.
\end{abstract}

Palavras-chave: Corporeidade, Educação, Dança.

\begin{abstract}
This article aims to understand the classroom as an affective space that we call here the "living room". In this way, it proposes to promote in the field of dance, through a perspective open to differences, the valorization of the study of corporeality, betting on ethics and poetics in the teaching-learning process. From an experience with a bachelor of dance students, we bring to the scene an educational experience that is interested in corporeality, in which the art of educating shows in its sensitive dimension its political power. We understand that it is necessary to find in the "disciplinary" action other modes of knowledge production, creating networks and weaving connections between knowledge.
\end{abstract}

Key-words: Corporeality, Education, Dance.

\section{Rodas de conversa, gira de pensamento...}

(...) E se tenho que usar-te palavras, elas têm que fazer sentido quase que só corpóreo, estou em luta com a vibração última. (...) Sim, quero a palavra última que também é tão primeira que já se confunde com a parte intangível do real. Ainda tenho medo de me afastar da lógica porque caio no instintivo, no direto, e no futuro (...). Estou lidando com a matéria-prima. Estou atrás do que fica atrás do pensamento. (...) É um estado de contato com a energia circundante e estremeço. Uma espécie de doida, doida harmonia. (...) (...) Posso não ter sentido, mas é a mesma falta de sentido que tem a veia que pulsa. (LISPECTOR, 1973, p.?)) 
O presente texto foi inspirado no encontro com alunos da Disciplina de Intercâmbios e Aprofundamentos nos Circuitos de Dança, disciplina oferecida aos alunos do $7^{\circ}$ período do Curso de Bacharelado em Dança da Universidade Federal do Rio de Janeiro. Essa disciplina tem o intuito de ofertar aos estudantes uma perspectiva ampliada dos variados campos de atuação da dança na cidade, contextualizando as diferentes práticas, saberes e públicos, incluindo espaços formais e não formais em dança.

O que nos move nessa escrita é o desejo de partilhar um processo de ensinoaprendizagem que se faz numa dinâmica diferenciada aos modos tradicionais das estruturas disciplinares. Dinâmica que se abre às múltiplas perspectivas sobre os espaços, os modos de relação e de produção de conhecimento em dança. Para essa dança com o pensamento, buscamos uma conversa entre nossas inquietações e as inquietações dos estudantes com a experiência na Disciplina. Assim, partiremos de uma abordagem metodológica em que o texto será tecido a partir de uma ressonância entre a escuta e a fala produzida no espaço de sala de aula.

\begin{abstract}
"Os intercâmbios em dança me levaram a um aprofundamento no estudo e em como iniciar uma pesquisa com interesse próprio (...) algo que seja instigante e interessante. Em qual tema aprofundar para chegar ao lugar que me representa em pesquisa e que seja interessante tanto no meu processo como para quem vai participar como público?" (Relato de estudante da disciplina)
\end{abstract}

Considerando o momento em que vivemos (vivenciamos) uma política arbitrária e engessada de pensamento, importa ainda mais sair de uma lógica tutelar em relação às práticas pedagógicas. Nesse viés, nos interessamos em evidenciar a potência crítica e criadora do corpo, despertando o interesse por projetos artísticos e pedagógicos mais autorais em dança que tratem o campo da dança fora dos cânones coloniais de pensamento que a tomam somente como entretenimento. Queremos afirmar na dança sua potência política, tecendo fios entre arte, educação, saúde e cultura, revisitando, reavaliando e experimentando encontros no exercício da troca, da reflexão e da crítica.

"Minha dança é terrena, reciclável e feita manualmente. (...) Como no meu fazer artístico eu posso tornar a dança um espaço aberto e acolhedor para corpos diversos? Vejo que minha posição artística está diretamente ligada à minha posição no mundo. (...)

Em meio a tantas políticas de desmontes e ataques à educação, cultura e arte pelo (des)governo atual, estar presente nos encontros, ouvindo e trocando experiências foi como encontrar brechas de escape para a construção de minha 
dança, utilizando de todo escombro e soterramento os materiais para construir meu espaço de dança." (Relato de estudante da disciplina)

Para a realização do aprofundamento nos circuitos da dança, propomos na disciplina exercitar a ação de fazer visitas e receber visitas, abordando os temas da dança-educação, dança e saúde, dança e cultura e companhias de dança. Recebemos visitas de profissionais da dança e áreas afins e alunos egressos dos cursos de dança da UFRJ. Visitamos também diferentes espaços de criação em dança. Buscamos com essa proposta a expansão e a diversificação dos olhares e perspectivas sobre o campo da dança. Convidamos também o pensamento dos nossos estudantes a dançar e a refletir sobre suas práticas e seus movimentos dentro e fora do espaço acadêmico.

Desejamos assim tecer no percurso dessa escrita uma intimidade com o texto, em que podemos desenvolver uma conversa entre "nós". Intencionamos promover uma ação dialógica entre alunos e professores, compreendendo nessa direção a costura dos pensamentos que são tecidos nas tranças múltiplas das falas, entre Eu, Você e Eles, nossos estudantes de dança.

São "nós" como substantivo e não como pronome pessoal. No entrelaçamento feito pelos fios ou linhas que nos unem, que não se findam e que se tecem nas e pelas conversas com muitos corpos, se fazem amarrações de saberes. Nós a receber, a trocar, a aprofundar experiências e a intercambiar realidades múltiplas na produção do conhecimento em dança, identificamos no que vai se mostrando em cores, formas e texturas variadas de um pensar o sentido da linguagem, à imagem de um Bricolage.

Um exercício coletivo que propõe no conjunto de trabalhos a arte de fazer o passatempo do pensamento, reflexão realizada de modo próprio e não especializado. Apostamos que é preciso romper os espaços conhecidos e costurar como pequenos consertos, com cuidado, outras possibilidades.

"Escritos sobre o aprofundar (...)

Acredito que os intercâmbios são fundamentais para trazer a interdisciplinaridade e a transdisciplinaridade que ronda a formação de qualquer estudante, trazendo pensamento crítico e visão de mundos paralelos, além de tirar o enrijecimento muitas vezes causado pelo sistema acadêmico. (...) Sigo pensando que a dança se dá além dos espaços convencionais de dança, além de ser necessário o pensamento de corpo colonizado que nos segue, A dança está no olhar, nas palavras não ditas e em qualquer reverberação que se manifesta." (Relato de estudante da disciplina) 
É preciso aprofundar na ação "disciplinar" seus modos de se fazer inter-transindisciplinar, produzindo tessituras, criando redes e tecendo conexões entre saberes, despertando desejo no processo de ensino-aprendizagem. Entendemos que a dança não é um domínio fechado em si, mas um campo aberto onde os pensamentos se atravessam no corpo. A dança se faz num plano aberto e complexo de relações, que se cruzam e que escapam da rigidez disciplinar. Por não se tratar de um domínio disciplinar, vive sempre na fronteira entre a educação, a arte, a clínica e a política.

Numa casa, a sala é um espaço de convivência e também a dependência principal destinada à recepção de visitas. Pretendemos ter como objetivo a compreensão da sala de aula numa Universidade Pública como um espaço de proximidades com a realidade, o qual denominamos "sala de visita".

Compreendemos que visitar é o ato de encontrar, que se dá pelo gesto de ir em direção ao outro. Visitar é encontrar, conhecer, dar e receber. No ato de visitar, podemos identificar no gesto de receber texturas variadas do pensar. A visita promove o encontro com o diverso pelo atravessamento que se faz na realização do diálogo. Nesse fluxo, o movimento torna-se o pensamento e a "sala de visita" torna-se o cenário que abre o corpo a outras narrativas, criando e ampliando suas possiblidades na dança.

\footnotetext{
"Dançar nas brechas não significa (...) permanecer nela, mas buscar alargar os espaços como processo de empatia para os novos iniciados na arte de dançar. Cada um que entra na brecha e amplia seu fazer, desestabiliza o que já está consolidado promovendo maior abertura e entendimento sobre o fazer dança. Cada brecha alargada permite a passagem de mais um e depois de mais um, essa rebeldia promove a mudança de dentro. Alargar os espaços é abrir para luz que num longo túnel possibilita ao artista a possibilidade. Se não houver lugar, busque a brecha (...)" (Relato de estudante da disciplina)
}

Nesse ponto, nos indagamos como transitar entre a poética e a ética no processo de educação em dança. Importa-nos incitar uma ação em que o espaço da sala de aula mova o espaço do corpo e o espaço do corpo redimensione, subverta e invente o espaço da sala de aula, se tornando sala de visita, espaço de afeto e compartilhamento de saberes e práticas.

Pensar o espaço da sala de aula como sala de visita é também mostrar um caminho que se faz presente na ação entre corpos: são olhares, posições e atitudes. Evidenciando no processo as relações e através delas o diálogo. Apresentamos as visões epistemológicas de modo menos engessado, trazendo o conhecimento de forma mais arejada, porosa e coletiva. 


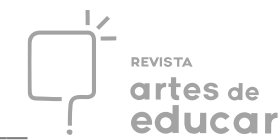

Buscamos nessa permeabilidade partir do corpo enquanto experiência e conhecimento, propondo uma ação investigativa mais integrada entre diferentes campos de atuação: educação, saúde, arte, cultura e política. Um fio que desenha em seu percurso uma trajetória sobre o que seja um intercambiar e aprofundar em dança, delineando um circuito que se faz por muitos caminhos. Nessa perspectiva, não podemos nos esquecer da reciprocidade dos corpos que se faz sem dicotomias nem hierarquias no processo de ensinar e aprender.

Como ser tomado pela coragem de criar? Ser tomado pela coragem de criar é um convite a outros lugares, uma abertura para possibilidades na circularidade das questões, que se mostra presente na reflexão das ações pelo mover do pensamento no corpo. Seria uma conversa, uma inquietação, um transbordamento que produz no movimento um conhecer não imposto e implicado, baseado no lugar da experiência do corpo, de um saber singular e plural, estendido, coletivo e compartilhado.

O movimento contínuo do pensar no agir provoca nos fios que se tecem o lugar do corpo. Esse lugar nos lança em sua urdidura à complexidade das questões, trançando, pouco a pouco, o caminho da linguagem, o entre que nos liga em sua ação ao Corpo, ao Movimento e à Educação.

Pelos caminhos do Educar chega-se aqui ao Dançar. E entre o dançar e o educar, o que há?

Afirmamos que nessa brecha, nesse entre, o que existe é corpo! Um corpo-mundo.

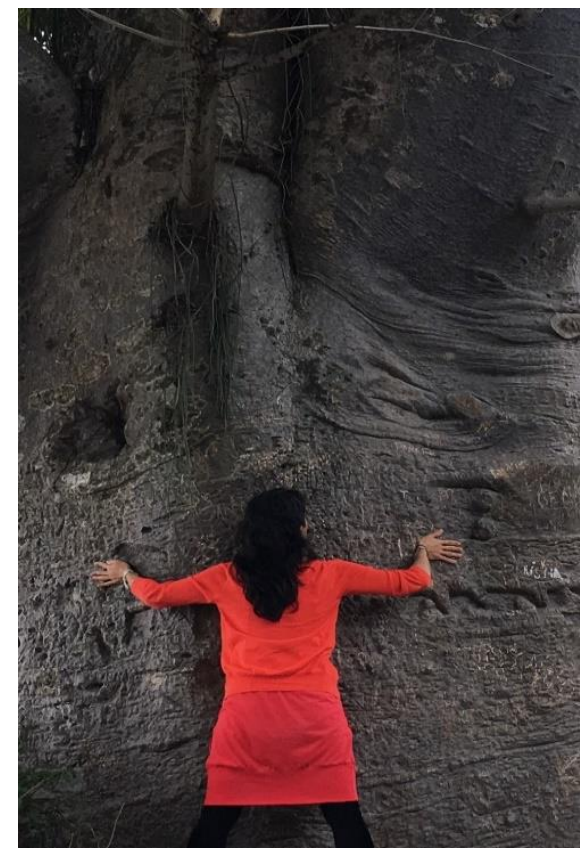

(Ilha de Paquetá)

Revista Interinstitucional Artes de Educar. Rio de Janeiro, V. 6, N.1- pág. 37-52 janeiro-abril de 2020:

"Educação: Corpo em movimento II." - DOI: 10.12957/riae.2020.45799 
A partir da perspectiva do ser-no-mundo, na presença que tem como princípio a corporeidade, esta trama de escrita se tece. $\mathrm{O}$ tecido dessa narrativa busca trazer a unidade do pensamento no corpo, visto em sua dimensão existencial, que se funda na trama da linguagem de todo realizar humano.

Baseando-se não mais num mundo de certezas, que busca explicar, na tentativa de dominar e apreender nos padrões estabelecidos, o pensar do corpo, sua luz, tal pensamento se direciona como contraponto à visão metafísica, a partir de uma determinada interpretação do corpo como questão e condição humana. Isso ocorre devido à impossibilidade de se identificar a corporeidade enquanto concretude de um espaço próprio, a saber, ser o que se é. Desconsidera-se assim o fenômeno, sem que se deixe reconhecer aquilo que se dá a ver através do corpo.

O que a dança pode no território da Universidade em relação a essa temática da corporeidade? Quais relações podemos traçar entre a educação em dança e a potência da vida no corpo?

\section{Seria a corporeidade na educação uma prática libertária?}

Entendemos o conceito de corporeidade como uma importante contribuição para tecermos práticas inclusivas abertas às singularidades. A corporeidade que afirmamos aqui é um dispositivo teórico-prático que acolhe, potencializa e afirma o corpo como um "movimento para". O corpo em sua abertura e devir na sua relação com o espaço e com o tempo.

A corporeidade é um conceito relativamente novo que abrange uma vasta área de investigação onde filosofia, história, sociologia, clínica, arte e política se atravessam, operando mudanças significativas no pensamento e nas práticas. Como aponta Marcus Machado (2006), o termo corporeidade se apresenta na atualidade em diversos campos de saberes, operando sentidos bastante variados. Com a ampliação das áreas que investigam o corpo, a corporeidade aparece como uma proposta inovadora, ora prática, ora conceitual, procurando operar uma saída aos reducionismos e dualismos, que subjugam o corpo a um lugar de menor valor em nossa cultura. Podemos destacar na corporeidade as práticas corporais que tentam abrir, nas experiências com o corpo, dimensões que envolvem a historicidade, a produção de subjetividade e a capacidade criadora do corpo e de sua gestualidade. 
A história da filosofia no Ocidente e, por consequência, os modos de apreensão do mundo na perspectiva ocidental operam preponderantemente por uma lógica dicotômica que ao criar polarizações privilegia um termo em detrimento do outro. Assim, temos o privilégio do pensamento em relação ao corpo, da razão em relação ao sensível, do masculino em relação ao feminino, do ocidental em relação ao oriental, do centro em relação à periferia, do branco em relação aos negros, indígenas, orientais e mestiços. A modernidade com sua perspectiva de humanidade centrada no modo-indivíduo racional, pautada pelo pensamento cartesiano, acirrou a perspectiva dualista e a desqualificação do corpo e da experiência sensível.

Podemos afirmar que ao longo do processo de "ocidentalização" da vida, disseminado pelo processo de colonização, o modo individual, racional, branco, ocidental operou uma política de pensamento de negação do corpo e da vida em seu plano sensível e intensivo. Entretanto, sabemos que a história desse processo é marcada também por fissuras e por movimentos de contraposição a lógica dominante.

A abordagem da corporeidade que evidenciamos se faz na relação do corpo com o mundo e toma a dança como território privilegiado para o exercício da criação de processos de subjetividades. A dança evidencia essa poética do corpo que se tece na relação da ação, da criação e da transformação.

A corporeidade é uma "aspiração" da dança (CALFA, 2006). Através da corporeidade tecemos um repertório sensível singular e um "universo simbólico" que possibilita fazer do conhecimento do corpo um sentido poético. A corporeidade traça uma trama poética através de um texto-tecido, uma narrativa própria: o corpo tece e é tecido por sua trama poética na sua relação com o mundo. A dança é uma manifestação de uma poética que faz emergir um lugar que "liberta", que libera as potências sensíveis do corpo.

Nesse sentido, a corporeidade dançante nos possibilita uma imagem para ver como um corpo se dilata e se cria segundo um espaço que é ao mesmo tempo interior e exterior. Podemos afirmar que, tramando relações entre interior e exterior do corpo, a dança nos faz ver o quanto somos mudas do espaço e, ao mesmo tempo, espaços privilegiados para tecer novas perspectivas do mundo. Daí emerge a necessidade de estarmos na dança sempre esculpindo o espaço do próprio corpo e o espaço ao redor para intensificar e ampliar as possibilidades do movimento.

Afirmamos assim que o primado da experimentação de si é o espaço da relação e que a corporeidade tomada em seu aspecto paradoxal é condição de possibilidade para a abertura ao plano intensivo e de imanência da vida. Plano esse que se opera numa certa relação com o 
tempo: um tempo gênese. O filósofo japonês Kunichi Uno (2012), seguindo uma linha de pensamento vitalista, se debruça sobre as obras dos dançarinos de butô Tanaka Min, Hijikata e do encenador teatral Artaud. Uno aborda, através da obra dessas artistas, uma dimensão do corpo como gênese: experiência em que corpo e vida são experimentados de modo indissociável através do tempo tomado em sua dimensão infinita.

Através de uma dança que ative uma presença do ser, Uno se interessa pela criação de um corpo anterior à palavra, à história, aos sentidos e ao nome próprio: um corpo estranho e estrangeiro, corpo-ovo, corpo-cosmos que toca o tempo. O corpo nessa relação com o tempo se torna matéria de devir. Para Uno o corpo é pura gênese que tem a força de envelopar o tempo nas dobras da carne. $\mathrm{O}$ tempo assim se abre com esse corpo que se desvencilha da organização anatômica e se refaz através dos fluxos intensos e flutuantes da vida. Uno afirma que a vida e o corpo são a mesma coisa. No entanto, para que a vida e o corpo se co-incidam e o corpo seja "digno" da vida, será preciso ativar sua força de gênese.

A dança desperta um mergulho da corporeidade na experiência com o tempo como útero do mundo, tempo intensivo, anterior à demarcação cronológica: tempo-gênese, tempo de criação. Deste modo, a dança ativa a escuta da corporeidade, a potência do corpo enquanto processo de permanente mudança e incessante transformação nesse movimento contínuo de se conhecer e se reconhecer junto às diferenças.

Precisamos vislumbrar a potência poética e política de uma educação pelo corpo que abarque nossa diversidade étnico-cultural. Num país tão plural e tão desigual como o Brasil é imprescindível considerar as multiplicidades que compõem as corporeidades e que inscrevem práticas de saber muito distintas das formais. Se pensarmos que a "arte" é uma palavra e uma categoria europeia, inscrita nos modos codificados das bases coloniais de pensamento, precisamos analisar quem pode viver e como pode viver de arte num país como o nosso.

Segundo o crítico literário Raymond Willians (2011), é difícil situar genealogicamente o surgimento da palavra "Arte" grafada com letra maiúscula e conceituada com princípios próprios. Até o século XVIII, a maioria das ditas ciências eram artes. A distinção moderna entre ciência e arte como áreas distintas e com métodos e finalidades diferentes remonta aos meados do século XIX. Segundo, Willians, os termos "artístico", "sensibilidade artística" e "temperamento artístico" também surgem nesse momento. No mesmo período, surge a diferença entre "artistas de espetáculo" como atores, dançarinos e cantores e simplesmente “artistas" para os pintores, escultores e em seguida escritores e compositores. 
Essas distinções e conceituações a respeito dos diferentes tipos de habilidades humanas estão intrinsecamente ligadas às mudanças na divisão prática do trabalho do mundo de produção capitalista. Nessa perspectiva, o artista se diferencia tanto do cientista e do tecnólogo como do artesão, do artificie (artífice?) e do trabalhador especializado, os ditos operários. Quando arte e mercadoria se relacionam a partir da lógica do capital, a arte se distancia do fazer cotidiano e o artista se distingue do artesão, as "Belas Artes" se distinguem da arte popular. A Modernidade assim como cria o sujeito moderno como modo-indivíduo, separa os cultos dos não cultos e cria os campos de saber lhe dando valor e significado.

Uma série de acontecimentos no mundo, a partir dos anos 60, irá alterar profundamente esta situação. Os processos de descolonização e de abertura política com o fim das ditaduras na América Latina, certamente tiveram um papel primordial: as ditas "minorias" assumiram voz na cena internacional, seja com os novos países africanos, seja com a emergência de organizações indígenas e quilombolas, que lutam pela sua autodeterminação face aos estados nacionais. É nesse mesmo momento que assistimos uma reativação da potência política do corpo no campo artístico-cultural.

Atravessados por essas perspectivas, alguns intelectuais e artistas brasileiros começam a problematizar a importância da arte no processo de educação, criando o conceito de ArteEducação. Esse movimento tem na figura da educadora brasileira Ana Mae Barbosa uma importante precursora. Através de pesquisas feitas entre os anos de 1974 e 1975 em algumas escolas públicas de $1^{\circ}$ grau na cidade de São Paulo, Ana Mae percebeu que os métodos e conteúdos eram os mesmos originários do século XIX que privilegiavam a constituição de uma elite, estimulando a formação de médicos e advogados (BARBOSA, 2012).

Com forte inspiração na figura do educador Paulo Freire, Ana Mae propõe a Educação como Prática de Liberdade. Considerando o contexto de um país que foi colonizado e que teve um projeto político de educação que tinha como objetivo ser uma educação das elites, visando manter a discriminação e exclusão social, Ana Mae Barbosa aposta na educação como transgressão, uma transgressão para a liberdade. Levando em consideração quem são esses corpos colonizados, essa perspectiva da educação percebe na arte uma potência de vida que vem sendo retirada da experiência e que está ligada, no plano do sensível, ao estudo da corporeidade.

Como nos lembra Michel Foucault (1996), a relação do corpo na educação, no modelo ocidental, se baseou na docilização e disciplinarização. Nesse sentido, a educação em dança, ao 
trabalhar as corporeidades, torna-se necessária e pode ser revolucionária por incidir diretamente na criação de modos de re-existência aos projetos colonizadores.

A corporeidade ao tornar o corpo mais sensível possibilita uma visão mais crítica da realidade. A experiência se faz no processo de dilatação intensiva dos limites topológicos do corpo, na sua relação extensiva e de continuidade com o espaço, com os outros corpos e com as forças do mundo: momento em que corpo e vida co-incidem, afirmando na potência criadora a ação transformadora.

A educadora feminista americana Bel Hooks (2017) aponta como o lugar concreto do sofrimento na cultura ocidental o corpo. A autora propõe que possamos aprender não só com os espaços de fala, como também com os espaços de silêncio para que no ato de ouvir possamos subverter a cultura do consumo imediatista e perturbar o imperialismo cultural segundo o qual somente algumas vozes têm legitimidade de fala. Reconhecer que através do lugar de fala em cada corpo é que podemos valorizar outras formas de linguagem. Afirmar que tocar e ser tocado de modos mais sensíveis e sutis é altamente revolucionário numa sociedade em que a paixão e o sentir são percebidos como marcas de inferioridade. Para a educadora, que também tem forte influência do educador Paulo Freire, mas que expande o pensamento libertário freireano, a educação pode ser guiada pelo princípio do prazer e da intimidade, rompendo com a distância hierárquica professor-aluno e com a obediência servil frente à autoridade do mestre e afirmando a potência de "Eros" na experiência de educar.

Como um bom "mestre ignorante" nas palavras Jacques Rancière (2015), devemos, mais que "informar" conteúdos, estimular a curiosidade de aprender. É preciso desaprender para melhor apreender com o estudante. Hooks (2017) afirma que o conhecimento e o pensamento crítico na sala de aula devem instruir nossos hábitos e modos de ser fora da escola, unindo teoria e prática e operando a educação para liberdade.

Podemos assim afirmar que o estudo da corporeidade é uma travessia e para realizar essa travessia é preciso fazer corpo-com. Uma corporeidade é um processo a ser gestado infinitamente. Por esse motivo que o corpo como entidade objetiva e identificada a um indivíduo não existe, sendo mera abstração, o que existe como materialidade sensível é uma corporeidade em movimento incessante de corporificar, o que existe são processos de corporeidade gestados no espaço-tempo. 


\section{Corpo-Travessia}

[...] Abriu-se uma pedra certa vez: os musgos eram frescos...

As plantas me ensinavam de chão. Fui aprendendo com o corpo.

Hoje sofro de gorjeios nos lugares puídos de mim. Sofro de árvores. (BARROS,1990, p. 148)

O corpo é o lugar onde somos chamados à vigência da corporeidade pela tessitura dos infinitos atravessamentos que ali se configuram em rede em sua travessia poética, isto é, presença. Trata-se de uma experiência do saber ver a coisa como se fosse a primeira vez, e deste modo se deixar atravessar e ser atravessado, se despir da significação das coisas, para que elas possam ser vistas em sua existência. Acordar a experiência inaugural de ser humano como a dos bebês, que não se sabem como unidade indiferenciada do mundo e que nesse jogo entre o ser e o mundo, se conhecem e conhecem o mundo. Logo, compreender na realidade que se apresenta o cultivar do ser, do ver e do dizer na força do conhecer.

Na presença se dá a potência. No desaprendizado das verdades estabelecidas, aceitas e repetidas passivamente, há a liberação das certezas estáveis e o lançar-se ao ensinar e aprender do corpo. Poder ser em sua dinâmica terra, árvore, germinação e pensamento chão.

O corpo se fazendo em gorjeios de si, ação e transformação, no tecer permanente que se faz na tensão de terra e mundo, desvelando-se em sua complexidade e deixando que o não visível se torne visível. Assim, surge para si mesmo pela plenitude de sentido na manifestação da linguagem, que conforme nos lembra Guimarães Rosa, é um Sertão, sem portas e janelas, assim como a terra, singular travessia.

$\mathrm{O}$ corpo dando-se à escuta é travessia. Torna-se o caminho para fazer na dimensão sensível e fértil a experimentação poética como abertura para construção do pensamento, na reflexão do habitar: questão, tensão, lugar e espaço. A partir da labiríntica teia que ali se enreda, a corporeidade se faz presente pelo habitar junto às coisas e aos lugares, na concepção do corpo morada. Espaço que ao se deixar atravessar é atravessado, não se deixa encapsular, por fazer de seu processo a transitoriedade no percorrer do tempo. A travessia enquanto manifestação emerge da necessidade permanente do corpo ao se dar e retrair como passagem e paisagem. É Revista Interinstitucional Artes de Educar. Rio de Janeiro, V. 6, N.1- pág. 37-52 janeiro-abril de 2020:

"Educação: Corpo em movimento II." - DOI: 10.12957/riae.2020.45799 


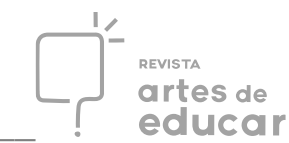

no atravessamento que encontramos a força da corporeidade pela correnteza da linguagem como movimento contínuo, no recolhimento e na expansão do corpo, entre gestos e palavras, ao mostrarem na travessia o caminho. O que é um caminho?

Caminho é o que se deixa alcançar. É o que, sendo escutado, nos deixa na fala da linguagem alcançar a saga do dizer. O caminho para a fala vigora na própria linguagem. (HEIDEGGER, 2001, p.205).

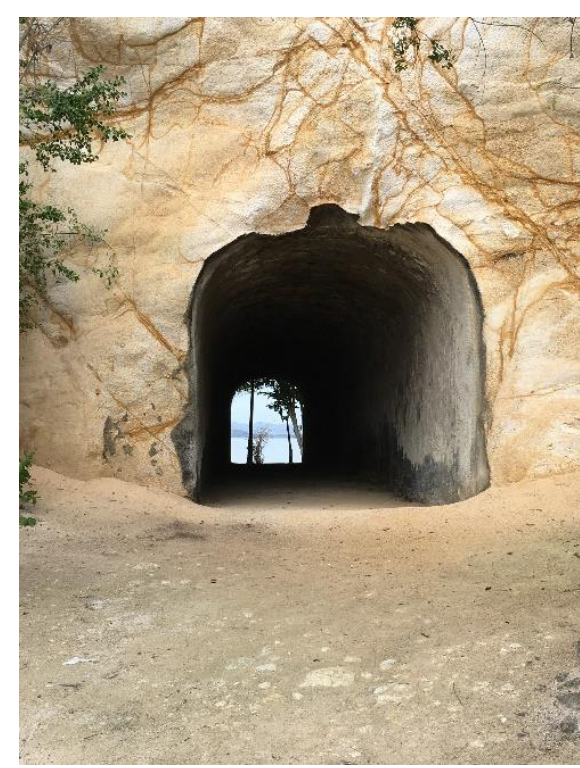

(Ilha de Paquetá)

Ao mostrar na travessia o caminho, reconhecemos pelos atravessamentos que encontramos a saga de um dizer que abriga o próprio da linguagem e em que deixamos o pensamento poético do corpo alcançar aqueles que a escutam.

Nesta correnteza da linguagem, a travessia nos leva ao caminho do pensamento, à saga de um dizer, à escuta e à fala do corpo, ao movimento que cria na trama as tessituras de uma narrativa em dança. Uma narrativa tecida de modo não uniforme e não linear, que não se traça pelo início, meio e fim de um percurso, e sim pelas diferentes direções e trajetórias que realizam nos entrelaçamentos concretizados pelo caminho. E o caminho é o caminho de pensamento, percepção e movimento do próprio corpo. O sentido emerge na busca da leitura de mundo. Ao ler, reunimos e recolhemos o construir da história, não cronológica, e sim ontológica do corpo, um tecer que não se faz pela sucessão dos fatos, mas fundamentalmente pela realidade que ali se condensa. Poeticamente, entrelaçamos, criamos, tecemos nas tramas que se desenham na escrita cuidadosa e lenta, entre nós e vazios, o sentido da própria existência. A linguagem e a 
vida se tecem no mesmo fio, juntas trazem no vigorar do corpo o tempo e o espaço. Essa ação vai, pouco a pouco, operando em sua urdidura a concretude de um dizer, revelando os caminhos de suas narrativas e trazendo no gesto as infinitas possibilidades.

O corpo tece a poesia da vida no movimento que não cessa. Tecendo somos tecidos. Construímos, ponto a ponto, no fluxo do movimento, o pensamento de uma escrita na produção da obra, do texto, do corpo, da dança. Desta forma, segue na travessia a narrativa, integrando no mosaico das partes o todo. É neste processo indissolúvel que somos reunidos pelas diferenças, tecendo na dança a trança múltipla e diversa da corporeidade.

O que pretendemos aqui é deixar que a travessia se faça na manifestação da fala e do gesto, dando voz aos sentidos do corpo e que o corpo em sua vigência poética viabilize o lugar da experiência como acontecimento, sendo tomado pelas questões, tornando-se abertura. Assim, o corpo parte do saber e procura no não saber um caminho de pensamento que o direcione ao extraordinário, encontrando na dança o desconhecido e o inaugural.

O corpo enquanto pensamento não se restringe ao raciocinar, mas se abre ao perceber no sentido de acolher e cuidar, de dar o que tem em si. Nesta perspectiva, focalizamos o corpo como lugar de ruptura de paradigmas, reconhecendo o deslocamento das questões que não se realizam na superficialidade das representações, nem na reprodução mecânica dos movimentos, vistos nos sistemas fechados e doutrinários do corpo, estabelecidos através de códigos dominantes que propõem definições de modelos e padrões de pensamento na dança.

Procuramos afirmar a importância do aprofundamento da linguagem e do pensamento do corpo no estudo da corporeidade e o despertar de uma ação dialógica no processo de nossos trabalhos artísticos-pedagógicos. Buscamos trazer em nossas práticas de aula o aceno ao que é próprio, e que aqui chamamos de estado de presença, ao que está para além do pensamento. Desejamos ir ao encontro ao que é essencial de um dizer, trazendo e recolhendo, dignamente, os méritos de um habitar que nos fala de um crescer com, desdobrado, concreto e edificado continuamente.

É preciso descer com profundidade ao solo de cada corpo, na permeável e úmida terra, e no húmus extrair os elementos necessários para novas germinações. A linguagem é nossa terra, chão de pensamento sobre o qual repousa o fundamento de sua morada ao trazer o corpo para o assentamento de si mesmo.

Seguimos percorrendo nas estranhezas e nas entranhas dos corpos as veredas, que se abrem como sulcos na terra, deixando o movimento se entregar ao destino do pensamento no encorajamento de toda e qualquer travessia. 
Mosaico de pedras e de gente

Tufão de memória

Um nó na garganta quente

Os olhos gritavam a dança daquela gente

Em raiz, corremos caminhos Percorremos mundos, sangrando em veredas estreitas

Sulcos, passo a passo...

\section{Conclusão}

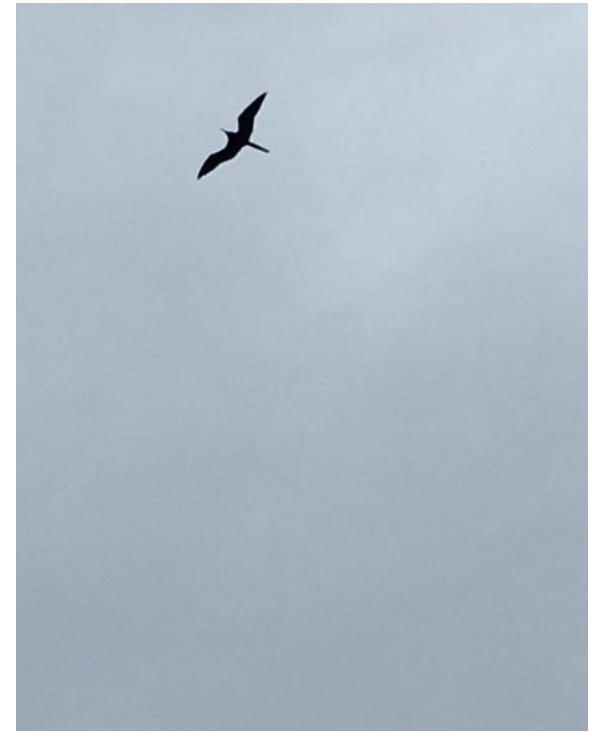

(Ilha de Paquetá)

Um vôo...

Vôo aberto ao livre pensamento do corpo, às quebras das certezas e à busca das questões.

Ao atravessar, aprofundar e trocar, lançamo-nos ao movimento da escrita em gesto e do gesto em escrita. Ao dançar e dialogar, nos colocamos num jogo tramado nas relações, nas investigações e nos com-textos com os campos de ação, criando complexas redes de saberes, despertando olhares mais críticos entre as visões epistemológicas e apresentando abordagens mais integradas e menos dicotomizadas entre teoria e prática no exercício de intercambiar experiências. 
A experiência é algo que nos acontece e que às vezes treme, ou vibra. É algo que nos faz pensar, algo que nos faz sofrer ou gozar, algo que luta pela expressão e que, às vezes, quando cai em mãos de alguém, é capaz de dar forma a esse tremor, então, somente então, se converte em canto. E esse canto atravessa o tempo e o espaço (LARROSSA, 2015, p.10)

Ressoando em outras experiências, a experiência cria espaços coletivos nas singularidades do pensar e do ser corpo, trazendo novos cantos que acordam olhares na experiência do ver, na construção crítica e no processo de elaboração e organização de projetos com compromissos mais ampliados e encantados na dança, estreitando ações poéticas e políticas. Enfim, criando brechas e abrindo caminhos, espaços e lugares de travessia.

A experiência da dança lançou vôos no corpo, no movimento e na educação em dança. Ao nos lançarmos no desconhecido do pensamento-corpo com nossos estudantes, na abertura de um saber compartilhado, tecemos juntos a trama ética e poética de afetos composta pelos fios da liberdade e do cuidado. Nesse sentido, apostamos no território do ensino-aprendizagem em dança na Universidade, o transbordamento da experimentação dos copos que considere o contexto, as singularidades, os modos de vida e a cultura dos lugares.

Para criar uma poética é preciso assim um sentido ético-político. Numa perspectiva de dança implicada com a questão do acolhimento e inclusão dos corpos e saberes dissidentes e não normativos, o processo de ensino-aprendizagem deve primeiramente acolher as materialidades sensíveis das corporeidades. É preciso estar atento à experimentação dos corpos, suas marcas e também as marcas dos territórios que os acolhem em suas práticas para que a educação como ação de liberdade e transformação seja um acontecimento.

É preciso criar nas brechas, nas bordas, nos espaços entre saberes e práticas para afirmar uma educação transgressora e libertária. É preciso ocupar corpos e ampliar territórios para criar fissuras numa política de pensamento que pretende limitar a potência sensível dos corpos "viventes de dança".

\footnotetext{
"Atuar na brecha é uma tarefa árdua que apela para a inteligência sensível. É preciso ser arteira para ocupar, e ocupar é de certo modo fazer rebeldia. Assim como os sem-terra que garimpam o espaço pela sua inteligência de ocupação de terras, o vivente de dança cria espaços nas fendas (...) Dançar na brecha é promover-se pelo instante (...)" (Relato de estudante da disciplina) .
} 


\section{REFERÊNCIAS}

BARBOSA, Ana Mae Arte-educação no Brasil São Paulo: Perspectiva, 2012.

BARROS, Manoel. A Gramática Expositiva do chão. Rio de Janeiro: Ed. Civilização Brasileira, 1990.

CALFA, M. I. S. Interdisciplinaridade e Dança. Revista Tempo Brasileiro n. 164. P. 65 a 80. Rio de Janeiro: Editora Tempo Brasileiro, 2006.

FOUCAULT, M. A Verdade e as Formas Jurídicas Rio de Janeiro: Nau, 1996.

HEIDEGGER, Martin. Ensaios e Conferências. Rio de Janeiro: Vozes, 2001.

HOOKS, B. Ensinando a transgredir: a educação como prática da liberdade São Paulo: Martins Fontes, 2017.

LARROSSA, Jorge. Tremores: Escritos sobre experiência. Belo Horizonte: Autêntica, 2015.

LISPECTOR, C. Água Viva. São Paulo: Círculo do Livro, 1973.

MACHADO, M. A Selvagem Dança do Corpo. Tese (Doutorado em...). Campinas: UNICAMP.

RANCIÈRE, J. O mestre ignorante. Belo Horizonte: Autêntica, 2015.

UNO, K. A gênese de um corpo desconhecido. São Paulo: N-1 edições, 2012.

WILLIANS, R. Cultura e Sociedade. Rio de Janeiro: Editora Vozes, 2011.

\footnotetext{
${ }^{\text {i }}$ Professora Associada dos Cursos de Dança e do Programa de Pós-Graduação em Dança da UFRJ, Rio de Janeiro, Brasil. https://orcid/000-0003-0910-1484, e-mail:miscalfa@ @otmail.com

ii Professora Adjunta dos Cursos de Dança e do Programa de Pós-Graduação em Dança da UFRJ, Rio de Janeiro, Brasil. https://orcid/0000-0002-6978-2478, e-mail:ruthtorralba@gmail.com
} 